\title{
Роль Митрополита Варшавського Діонісія Валединського в конституюванні УАПЦ формації 1942 року
}

\section{Rola Metropolity Warszawskiego Dionizego Waledyńskiego w ukształtowaniu Ukraińskiego Autokefalicznego Kościoła Prawosławnego formacji 1942 roku}

Artykuł jest poświęcony zewnętrznym przemianom ukraińskiego prawosławia w latach II wojny światowej. Szczególną uwagę zwrócono na stosunki kanoniczne między Metropolią Warszawską i Patriarchatem Moskiewskim. Pod okupacją niemiecką prawosławie ukraińskie zostało podzielone na dwie grupy. Autonomiczny Kościół Prawosławny zarządzony przez metropolitę Aleksego Hromadskiego uznawał jurysdykcję Patriarchatu Moskiewskiego. Metropolita Warszawski Dionizy Waledyński popierał ustanowenie Ukraińskiego Autokefalicznego Kościóła Prawosławnego i mianował arcybiskupa Polikarpa Sikorskiego administratorem tego Kościóła na ziemiach Ukrainy. Sikorski w lutym 1942 r. w Pińsku wyświęcił dwóch nowych ukraińskich władyków (Nikanora Abramowicza i Ihora Hubę). W maju 1942 r. w Kijowie Sobór Biskupów UAKP nadał Dionizemu godność locum tenens metropolii kijowskiej.

Słowa kluczowe: Dionizy Waledyński, Kościół prawosławny, Metropolia Warszawska, kanoniczność, hierarchia 
Українське церковне питання впродовж усього ХХ ст. було своєрідним «яблуком розбрату» між Москвою, Константинополем і Варшавою. Це стосується як автокефалії, проголошеної собором Української автокефальної православної церкви (УАПЦ) 1921 р. у Києві, так і польської автокефалії, дарованої томосом Константинопольського Патріарха у 1924 р. православній церкві в Польщі, більшість парафій якої були українськими. Під час Другої світової війни в Україні також гостро стояло питання про шляхи досягнення автокефалії, що й спричинило інституційний розкол православної церкви.

Історія українського православ'я в роки Другої світової війни продовжує привертати увагу дослідників, породжує палкі наукові й суспільні дискусії. Вагомий внесок у наукове вивчення цієї проблеми здійснили В. Борщевич, І. Власовський, Ю. Волошин, О. Лисенко, о. Тимофій Міненко, В. Пащенко, С. Савчук, Ю. Мулик-Луцик, Н. Стоколос та інші автори. Водночас дотепер недостатньо досліджена роль митрополита Варшавського Діонісія Валединського в конституюванні УАПЦ формації 1942 р.

Костянтин Миколайович Валединський (1876-1960) народився у м. Муромі Володимирської губернії у родині священика. Закінчив Казанську духовну академію. У 1897 р. прийняв чернечий постриг. 31902 р. він - архімандрит, ректор Холмської духовної семінарії, а 31911 p. - настоятель храму при російському посольстві у Римі. У 1913 р. згідно з рішенням Святішого синоду Російської православної церкви (РПЦ) його обрали єпископом Кременецьким, вікарієм Волинської єпархії. 21 квітня 1913 р., у Фомину неділю, у Великій церкві Почаївської лаври сонм ієрархів на чолі з Патріархом Антіохійським Григорієм IV Хаддадом, який перебував у цей час у Росії з офіційним візитом, здійснили його архієрейську висвяту. Прикметно, що Григорій IV через тиждень також очолив єпископську хіротонію Олексія Симанського, майбутнього Московського Патріарха. Після цього владика Діонісій опікувався Холмською і Поліською єпархіями. У 1918 р. він брав участь у Всеукраїнському 
церковному соборі, де на третій сесії очолював комісію з українізації богослужіння. Владика став головою Собору єпископів усієї України (грудень 1918 - січень 1919 р.). У 1919 р. його запросили до Синоду української церкви, але від цієї пропозиції він відмовився. Спископ співпрацював із Міністерством ісповідань УНР, опікувався духовними потребами вояків армії УНР, інтернованих у Польщі. У 1922 р. його призначили архієпископом Волинським і Кременецьким. Упродовж 1923-1948 рр. він був предстоятелем православної церкви в Польщі. У міжвоєнний період займав обережну позицію щодо українізації церкви, але сприяв висвяченню проукраїнськи налаштованих єпископів, зокрема хіротонізував Полікарпа Сікорського, згодом - Іларіона Огієнка та Палладія Видибіду-Руденка. У 1940-х рр. був формальним кіріархом УАПЦ. Помер 15 березня 1960 р. у Варшаві, похований на Вольському цвинтарі ${ }^{1}$.

У роки німецької окупації в Україні існували дві основні православні юрисдикції. Це Автономна православна церква на чолі 3 митрополитом Олексієм Громадським, що позиціонувалася як частина Московського патріархату, та Українська автокефальна православна церква, очолювана іiі тимчасовим адміністратором - архієпископом (з жовтня 1942 р. митрополитом) Полікарпом Сікорським, яка перебувала під омофором Варшавської митрополії православної церкви в Генерал-губернаторстві ${ }^{2}$. Канонічно-юрисдикційна залежність двох українських православних церков від закордонних релігійних центрів, які постійно конфронтували, об'єктивно ускладнювала православне церковне життя, створювала перепони в об'єднанні церков. Це давнє протистояння в українському православ’ї слід розцінювати як найбільш послідовний та інституційований конфлікт ідентичностей і пошук відповідних

${ }^{1}$ S. Dudra, Metropolita Dionizy (Waledyński). 1876-1960, Warszawa 2010.

${ }^{2}$ В. Борщевич, Автономна Православна Церква на Волині, Луцьк 1998; Н. Стоколос, Конфесійно-етнічні трансформації в Украӥні (XIX - перша половина ХХ ст.), Рівне 2003. 
їм моделей канонічного устрою. Кардинальні політичні трансформації в новітній історії України неминуче сприяли до піднесення неасимільованих російським православ'ям елементів, актуалізації проблеми унезалежнення православної церкви в Україні.

У вересні 1940 р. Митрополит Варшавський Діонісій Валединський повернувся до управління православною церквою в Генерал-губернаторстві й вже на другий день німецько-радянської війни звернувся до німецької влади з проектом відновлення своєї юрисдикції на сході на підставі того, що значна частина земель (Волинь, Полісся) до 1939 р. входила до Варшавської митрополії, а більша частина його єпископату залишилася на цих теренах. 28 червня 1941 р. він звернувся з окремим посланням до духовенства і вірних Волині, а також написав листи до своїх колишніх архієреїв ${ }^{3}$. 10 липня єпископ Луцький Полікарп Сікорський підпорядкував собі Рівненський, Дубенський і Кременецький повіти.

Під впливом уенерівських діячів у Варшаві митрополит Діонісій змушений був ухвалити доволі радикальне рішення, яке значно ускладнило міжправославні відносини на Волині. 11 серпня 1941 p., коли німецькі війська вже зайняли волинські землі, він надіслав декрет владикам Олексію, Полікарпу і Олександру, в якому констатував відновлення канонічного зв’язку з ними, пропонував скликати архієрейський собор у Кременці або Почаєві для впорядкування церковного життя, розпорядився знову розділити Волинську єпархію на дві частини: Кременецьку - під управлінням архієпископа Олексія Громадського, та Луцьку - на чолі з владикою Полікарпом Сікорським, піднесеного цього ж дня до сану архієпископа Луцького і Ковельського. На владику Симона Івановського покладалися обов'язки вікарного єпископа на території Кременецької єпархії з резиденцією в Острозі. Управління Поліською єпархією, згідно з декретом, залишалося за архієпископом Олександром

${ }^{3}$ Т. Міненко, Православна Церква в Україні під час Другої світової війни. 1939-1945 (Волинський період), т. 1, Winnipeg, Львів 2000, с. 217-219. 
Іноземцевим. Йому ж окремим листом під тимчасову опіку віддавалася Гродненська єпархія. Архієпископ Антоній Марценко мав залишатися вікарним єпископом Поліської єпархії. Висвячені за радянської влади єпископи Пантелеймон Рудик і Веніамін Новицький втрачали частину своїх повноважень разом з офіційними титулами та призначалися настоятелями відповідно дубенського Хрестовоздвиженського і дерманського Свято-Троїцького монастирів ${ }^{4}$. Усе духовенство цих єпархій мало поминати владику Діонісія згідно з такою формулою: «Владику нашого, Блаженнійшого Діонісія, Митрополита Варшавського і всієї Святої Автокефальної Православної Церкви нашої, Священноархимандрита Почаєво-Успенської лаври» ${ }^{5}$. Такі кадрові зміни лише загострили стосунки між єпископатом на території Волині й Полісся та Варшавським митрополитом, юрисдикцію якого визнали тільки два архієреї - Олександр і Полікарп. «Декрет митр[ополита] Діонісія виявився передчасним, який довершив церковне розбиття на Волині, яке поширилося пізніше і на всі українські області», - зазначав о. Т. Міненко 6 .

Група занепокоєного духовенства на чолі з архієпископом Олексієм не визнала юрисдикції митрополита Діонісія. 18 серпня 1941 p. на обласному соборі єпископів у Почаєві владики Олексій Громадський, Симон Івановський, Пантелеймон Рудик і Веніамін Новицький проголосили створення Автономної православної церкви в складі Московського Патріархату, очільником якої обрали владику Олексія. По суті, почаївські рішення, не визнані ні Варшавою, ні Москвою, започаткували інституційний розкол українського православ'я в роки війни ${ }^{7}$.

${ }^{4}$ Archiwum Warszawskiej Metropolii Prawosławnej (AWMP), sygn. 1151-RII-6D (Cerkiew ukraińska w latach 1939-1944).

${ }^{5}$ Ibidem.

${ }^{6}$ University of Alberta Archives, Accession 2011-27 (Minenko Collection), box 57, item 1404.

${ }^{7}$ А. Смирнов, Почаӥвський иерковний Собор 18-23 серпня 1941 року, «Наукові записки Національного університету „Острозька академія”. Серія „Історичні науки"» 2015, вип. 24, с. 61-66. 
Власне бачення ситуації у листі до владики Олексія (23 жовтня 1941 р.) окреслив митрополит Діонісій. Рішення архієрейського зібрання він уважав неправомірним з кількох причин: по-перше, підпорядкування православної церкви в Україні РПЦ неможливе внаслідок того, що «під теперішню пору не існує правильної й на засадах канонічних організованої Церкви російської», по-друге, православна церква в Україні, згідно з томосом Константинопольського Патріарха від 13 листопада 1924 р., була незалежною церквою і «перебувала в канонічному зв'язку з великою Церквою Царгородською»; по-третє, оскільки канонічне право забороняло поширювати повноваження одного церковного об'єднання за рахунок іншого, «Московська Патріархія з їі місцеблюстителем митрополитом Сергієм, підпорядковуючи собі терени нашої св[ятої] Автокефальної Церкви, поступала всупереч приписів канонічних $)^{8}$.

Собор єпископів у Генерал-губернаторстві 28-29 жовтня 1941 р. уважав церковну ситуацію на Волині та Поліссі невпорядкованою і доручив Діонісію скликати спільний архієрейський собор 9.13 листопада 1941 р. він ще раз визнав постанови почаївського «псевдособору» недійсними і всю вину за «хаос в церковно-парафіяльному житті» поклав на автономістів ${ }^{10}$. В іншому листі 20 січня 1943 р. Діонісій дорікав Олексію: «Ви відійшли від свого кіріарха, не мавши від нього на це не тільки ніякого дозволу, але навіть всупереч його ясно висловленій волі. Це Ваше відступництво... і з'явилось причиною нещасть, ставши першою спонукою падіння дисципліни та початком безладдя в церковнім житті в Україні... Тож я давно мав канонічну можливість застосувати заборони, але я не стосую суво-

${ }^{8}$ Мартирологія Українських Церков. Т. 1. Українська Православна Церква, Toronto, Baltimore 1987, c. 681-683.

${ }^{9}$ Т. Міненко, ор. cit., с. 293.

${ }^{10}$ В. Борщевич, Украӥнське черковне відродження на Волині (20-40-ві рр. $X X$ cm.), Луцьк 2000, с. 138. 
рости „по даній мені Господом владі для будування, а не для руйнування" (2 Кор. 13, 10)» ${ }^{11}$.

Паралельно з цими процесами в Україні почав розгортатись автокефальний рух. Ейфорія перших місяців німецької окупації активізувала національно-церковні процеси; у середовищі української інтелігенції виник потяг до створення УАПЦ, яка була б цілковито унезалежнена від будь-якого закордонного релігійного центру. Щоправда, поки прихильники автокефалії дискутували і з великим запізнення засуджували діяльність автономістів, найсприятливіший час для конституювання УАПЦ було згаяно.

Сьогодні більша частина дослідників пов'язує виникнення УАПЦ формації 1942 р. з так званим декретом митрополита Діонісія від 24 грудня 1941 р. У цьому листі до архієпископа Полікарпа Сікорського повідомлялося: «На просьбу православних церковних рад Волині від 14 грудня ц. р., я постановив утворити Тимчасову адміністратуру нашої св[ятої] Автокефальної Православної Церкви на визволених українських землях. Тимчасовим адміністратором призначую Ваше Високопреосвященство і прошу Вас співпрацювати з Високопреосвященнішим архієпископом Олександром. Про всі Ваші проекти й розпорядження прошу негайно мене сповіщати для надання їм остаточної канонічної санкції» ${ }^{12}$.

Із авторитетних свідчень Ю. Мулика-Луцика, що був свідком подій, пов'язаних зі встановленням адміністратури, та із виявлених останніми роками архівних документів стає зрозуміло, що проблеми українського православ'я надзвичайно турбували діячів Української Народної Республіки (УНР) на чолі з А. Лівицьким, які у Варшаві мали великий вплив на митрополита Діонісія. Вони уважно стежили за всіма подіями православного церковного життя на теренах Райхскомісаріату «Україна» i, знаючи, що Діонісію за-

${ }^{11}$ AWMP, sygn. 1151-RII-6D.

${ }^{12}$ Ibidem; А. Смирнов, Мстислав (Скрипник): громадсько-політичний і иерковний діяч. 1930-1944, Київ 2008, с. 257-259. 
боронено втручатися в церковні справи поза Генерал-губернаторством, доклали чимало зусиль для того, щоб дістати в Берліні дозвіл ввести в його юрисдикцію православні громади з українських земель. Хоча 2 листопада 1941 р. такий дозвіл вони отримали, одначе вже 21 листопада членам делегації Варшавської митрополії у Берліні єпископу Тимофію Шреттеру і професору О. Лапинському роз'яснили, що, по-перше, встановлюється лише «тимчасову адміністратуру», а, по-друге, іiі діяльність цілковито залежатиме від волі й відповідних розпоряджень рейхскомісара Е. Коха ${ }^{13}$.

Нарада уенерівців 30 листопада у Варшаві за участю А. Лівицького і владики Палладія Видибіди-Руденка ухвалила рішення про підтримку кандидатури архієпископа Луцького і Ковельського Полікарпа Сікорського на адміністратора. Він був єдиним в Україні архієреєм-українцем, який залишився вірним митрополиту Діонісію $^{14}$. Останній ще 13 листопада на прохання Київської церковної ради благословив Полікарпа здійснити архіпастирський візит до Києва і навіть висвятити разом з Олександром нового єпископа ${ }^{15}$. Оскільки діячі УНР у Варшаві визнали, що «незручно» призначати Сікорського «не $з$ волі свого народу», то й було зорганізовано засідання «Наради представників церковних рад Волині» в Рівному 13 грудня 1941 p. $^{16}$

У результаті було створено комісію в складі С. Скрипника, Н. Кибалюка, М. Середюка і Ю. Мулика-Луцика. 14 грудня 1941 р. вона підготувала листа уповноважених від церковних рад Волині до митрополита Діонісія, у якому висловлювала прохання: «1) вжити всієї своєї влади в церкві і всіх можливих засобів до припинення

${ }^{13}$ Н. Стоколос, op. cit., с. 318.

${ }^{14}$ T. Міненко, op. cit., с. 299-301.

15 Державний архів Київської області, ф. 2412 (Музей-архів переходової доби), оп. 2, спр. 199, арк. 29-31, 75.

${ }^{16}$ С. Савчук, Ю. Мулик-Луцик, Історія Украӥнської Греко-Православної Церкви в Канаді. Т. 1. Київська церковна традиція українців Канади, Winnipeg 1984 , c. 503-509. 
розкладкової в церкві діяльності архієпископа Олексія, цілковито до усунення його з кафедри та приділення до якогось 3 монастирів, причому запевнюємо Ваше Блаженство, що в своєму рішенні Ви можете опертися на однозгідну думку українського православного громадянства, організованого в церковних радах Рівного, Дубна, Кременця, Луцька; 2) доручити тимчасове адміністрування Православною церквою на українських землях, звільнених від більшовицької влади, архієпископові Луцькому і Ковельському Полікарпові, при якому зараз вже є і надалі повинна бути єпископська рада $з$ представників духовенства і мирян, голос якої, згідно давніх соборних українських традицій в церкві, мусить мати все своє значення в питаннях церковно-адміністративного характеру; 3 ) поблагословити архієпископам Полікарпові і Олександру Поліському висвячувати єпископів українців для делегації їх в цілі виконування архіпастирських обов'язків на Схід» ${ }^{17}$.

Зі створенням адміністратури Варшавської митрополії в українських землях було започатковано процес конституювання УАПЦ в роки війни. В українській церковній історіографії на означення цієї еклезіальної структури узвичаєно термін «УАПЦ формації 1942 р.». Його часто використовував у своїх працях Іван Власовський на противагу терміну «УАПЦ формації 1921 р.» ${ }^{18}$.

Щодо стосунків з Варшавською митрополією, то, на його думку, юрисдикція митрополита Діонісія «зводилась властиво до духовної опіки над Українською автокефальною (de facto) Церквою» ${ }^{19}$. Офіційний предстоятель української церкви владика Діонісій не мав можливості повноцінно виконувати канонічно-ієрархічні функції. Тому, попри те, що формально УАПЦ залишалася в складі православної церкви в Генерал-губернаторстві, можна вважати ії самодо-

${ }^{17}$ AWMP, sygn. 1151-RII-6D.

${ }^{18}$ I. Власовський, Нарис історії Украӥнської Православної Церкви. Т. 4. ХХ ст. Ч. 2, Київ 1998, с. 365, 371.

${ }^{19}$ Ibidem, c. 226. 
статнім еклезіальним організмом зі своїм собором єпископів і адміністратором владикою Полікарпом Сікорським.

3 іншого боку, як видно з декрету та інших історичних джерел, усі головні події в житті церкви, зокрема створення ієрархії УАПЦ, відбувалися з благословення канонічного зверхника Варшавського митрополита Діонісія, ім'я якого повинно було поминатись єпископами у всіх кафедральних храмах УАПЦ.

Отже, декрет владики Діонісія від 24 грудня 1941 р. став першим кроком на шляху до організаційного оформлення УАПЦ як помісної церкви $з$ канонічним єпископатом. Іншого варіанта розвитку подій, враховуючи відсутність власної державності, за тих умов просто не існувало. Це було значним досягненням українського автокефального руху після неоднозначних спроб започаткувати власну ієрархію в $1921 \mathrm{p}$.

Владики розуміли вразливість канонічного статусу УАПЦ, яка потребувала вселенського визнання, тому 18 грудня 1942 р. архієпископ Никанор Абрамович писав митрополиту Діонісію Валединському: «Чи не вважали би Ви, Ваше Блаженство, за своєчасне і слушне занотифікувати Українську Православну Церкву у інших сестер-церков як рівнорядну автокефальну одиницю. Одночасно, річ очевидна, прийшлося б Вам, як первоієрарху і голові матірної Церкви нашої, поблагословити Українську Православну Церкву на автокефальне життя, поки ще дорогою радіовою „червоний патріарх” не поблагословив на таке життя нашого московського одламу» ${ }^{20}$.

Ще наприкінці грудня 1941 р. владика Палладій Видибіда-Руденко заявив, що через відсутність української державності Фанар не наважиться надати автокефалію українській церкві. Допомогти у цьому питанні зможе тільки владика Діонісій, проголосивши себе Митрополитом Київським і всієї України ${ }^{21}$. У свою чергу, Митропо-

${ }^{20}$ AWMP, sygn. 1151-RII-6D.

${ }^{21}$ Центральний державний архів громадських об'єднань України, ф. 269, оп. 1, спр. 341, арк. 28-30. 
лит Варшавський повідомляв, що Константинопольський Патріархат з великим зацікавленням спостерігає за подіями в церковному житті України і підтримує «церковно-канонічну лінію» Діонісія. Останній наполягав на тому, що автокефалію треба здобувати тільки канонічним шляхом на основі патріаршого і синодально-канонічного томосу Вселенського Патріархату 1924 р., але не запропонував жодної моделі конституювання помісності української Церкви, чекаючи на завершення війни ${ }^{22}$. До речі, як вважав о. Т. Міненко, саме різні погляди православних ієрархів на автокефалію польської церкви стали центром розбіжностей і справжньою причиною інституційного розколу в українському православ”і, що виявилось в антагоністичних концепціях церковного відродження в Україні владик Діонісія, Іларіона і Олексія ${ }^{23}$.

Одним із найсерйозніших викликів перед УАПЦ була катастрофічна нестача архієреїв. У зв’язку з цим уже в лютому 1942 р. у Пінську владика Полікарп за допомогою архієпископа Пінського і Поліського Олександра Іноземцева розпочав висвяту єпископів для української церкви. Першими були хіротонізовані Никанор Абрамович та Ігор Губа. У травні 1942 р. під час проведення архієрейського собору УАПЦ у Києві була рукоположена нова група ієрархів. Одним із них став Степан Іванович Скрипник - посол до польського сейму від Волині в 30-х pp. ХХ ст., майбутній першоієрарх Української православної церкви в США, перший Патріарх Київський і всієї України Мстислав. Київський собор підтвердив визнання за митрополитом Діонісієм Валединським повноважень місцеблюстителя київського митрополичого престолу. Протоколи архієрейських свячень надіслали до Варшавського Митрополита, і він затвердив їх листом від 16 червня 1942 року $^{24}$.

Сучасна російська конфесійна історіографія продовжує експлуатувати гасла радянської пропаганди про неканонічність і безблаго-

\footnotetext{
${ }^{22}$ AWMP, sygn. 1151-RII-6D.

${ }^{23}$ Про це детальніше див.: Т. Міненко, op. cit., с. 11, 217-240.

${ }^{24}$ I. Власовський, op. cit., с. 223.
} 
датність ієрархії воєнної УАПЦ. Вона базує свої малопереконливі аргументи на популярному міфі про те, що владика Полікарп у 1940 p. разом з усіма православними єпископами Західної України і Західної Білорусі перейшов у підпорядкування РПЦ25.

Нині достеменно відомо, що ані архієпископ Поліський і Пінський Олександр Іноземцев, ані єпископ Луцький Полікарп Сiкорський до Москви для оформлення «молитовно-канонічного поєднання з Матір'ю-Церквою Московською» не їздили і жодних письмових декларацій про це не підписували. За таку нелояльність першого відправили «за штат», а другого просто не встигли покарати $^{26}$.

I все ж у великодньому посланні 1942 р. за «змову єпископа Полікарпа з фашистами» місцеблюститель московського патріаршого престолу Сергій Страгородський проголосив йому «позбавлення сану й чернецтва -3 виключенням із духовного звання» ${ }^{27}$. Це було порушення канонічних норм і втручання у внутрішні справи іншої помісної церкви, тому владика Полікарп ніколи не визнавав цих рішень. Аналіз постанови архієрейського собору РПЦ від 28 березня 1942 р. свідчить, що вона містить тільки погрозу накладення канонічних санкцій без жодних імперативних норм. Остаточне рішення в справі владики Полікарпа мав прийняти церковний суд ${ }^{28}$. Однак це не завадило московській церкві надалі вважати все автокефальне духовенство безблагодатним. 3 цього приводу Синод РПЦ 15 квітня 1948 р. зауважив, що лише

${ }^{25}$ В. Петрушко, Автокефалисткие расколь на Украине и проблема их преодоления: канонический аспект [online], http://archive.li/uU5P [доступ: 19.11.2017].

${ }^{26} \mathrm{~A}$. Mironowicz, Kościót prawostawny na ziemiach polskich w XIX i XX wieku, Białystok 2005, s. 224; Н. Стоколос, op. cit., c. 291.

${ }^{27}$ Божиею Милостию, возглавляющий Православную Русскую Церковь, патриарший местоблюститель, смиренный Сергий, митрополит Московский и Коломенский православным архипастырям, пастырями пасомымм в областях Украины, пока еще занятых гитлеровскими войсками [online], http://www. sedmitza.ru/text/439907.html [доступ: 30.11.2017].

${ }^{28}$ Мартирологія Украӥнських..., с. 654-655. 
ті висвяти владики Полікарпа, які були здійснені до березня 1942 p., $є$ канонічними ${ }^{29}$.

Таким чином, аналіз історичних джерел спростовує звинувачення у неканонічності єпископських хіротоній архієреїв УАПЦ. Емігруючи через Варшаву на Захід у травні 1944 року всі архієреї УАПЦ дістали спеціальні довідки від митрополита Діонісія, у яких зазначалося, що вони отримали 3 його благословення канонічну хіротонію й, перебуваючи з ним та святішими православними патріархами в канонічній єдності, «належать до єпископату Св[ятої] Вселенської Православної Церкви» ${ }^{30}$. Варто згадати, що коли по війні у РПЦ виникло питання, що робити з єпископом Юрієм Кореністовим, котрий став берестейським архієреєм на Пінському соборі, то після певних роздумів його прийняли до складу Московського Патріархату без пересвяти. У 1995 р. усе духовенство УПЦ у США, яке походило від владики Мстислава Скрипника, без будь-яких застережень увійшло до складу Константинопольського патріархату. Тому законність їх єпископських свячень не повинна викликати жодного сумніву.

Вимушена еміграція української ієрархії на Захід сприяла тому, що вперше більшість архієреїв УАПЦ опинились в одному місці й отримали можливість безперешкодно спілкуватися, перебуваючи під опікою Варшавського Митрополита. 3 метою розв'язання нагальних церковних проблем у нових умовах та пошуку порозуміння між ієрархами був скликаний перший еміграційний собор єпископів УАПЦ. Він відбувався у Варшаві з 11 березня по 8 квітня 1944 р. під головуванням митрополита Полікарпа (Сікорського) і за участю ще 9 єпископів. На соборі було прийнято «Тимчасове положення про управління святої Української Автокефальної Пра-

${ }^{29}$ Н. Шліхта, Церква тих, хто вижив. Радянська Украӥна, середина 1940-х початок 1970-х рр., Харків 2011, с. 129.

${ }^{30}$ А. Дублянський, Тернистим иляхом: життя митрополита Ніканора (Абрамовича), London 1962, с. 46. 
вославної Церкви» і створено Св. Синод як виконавчий орган собору $^{31}$.

8 квітня 1944 р. група архієреїв УАПЦ (Никанор, Геннадій, Платон, Володимир, Сергій, В'ячеслав) на чолі 3 митрополитом Полікарпом звернулись у письмовій формі до митрополита Діонісія 3 проханням «прийняти від нас почесний титул Патріарха, що правдиво прислуговує Вашому Блаженству, як Голові Православної церкви в Генерал-губернаторстві, многолітньому досвідченому Керманичеві iï та Високому Покровителеві Української автокефальної православної церкви» ${ }^{32}$. У листі до блаженнішого Діонісія від 8 квітня 1944 р. владики Ігор, Мстислав, Сильвестр цілком справедливо звернули увагу на те, що на засіданні собору питання надання титулу патріарха не розглядалося, а тільки ухвалили рішення поминати митрополита під час архієрейських богослужінь ${ }^{33}$.

12 квітня 1944 р. владика Мстислав повідомив начальника відділу внутрішнього управління при губернаторі Варшавського дистрикту про надання титулу патріарха митрополиту Діонісію. Дізнавшись про це, керівник групи церковної політики при східному міністерстві Карл Розенфельдер терміново вилетів до Варшави, щоб провести переговори з православними владиками. Влада гостро відреагувала на таке рішення і заборонила його впроваджувати, позаяк це не відповідало політиці Німеччини ${ }^{34}$. Нам так і не вдалося віднайти документи, в яких владика Діонісій титулувався б патріархом, хоча дехто стверджує, що його так згадували під час богослужінь у храмах УАПЦ ${ }^{35}$.

${ }^{31}$ I. Власовський, op. cit., с. 273-274.

${ }^{32}$ AWMP, sygn. 1151-RII-6D.

${ }^{33}$ Ibidem.

${ }^{34}$ A. Mironowicz, op. cit., s. 227; М. Шкаровский, Политика Третьего рейха по отношению к Русской Православной Церкви в свете архивных материалов (сборник документов), Москва 2003, с. 103.

${ }^{35}$ [С. Ранєвський], Украӥнська автокефальна иерква: історичний нарис про иерковний розкол на Україні, Хмельницький 1995, с. 16. 
Одним із концептуальних моментів, що потребують з'ясування, $\epsilon$ питання про те, які наслідки для конституювання УАПЦ в еміграції мали рішення архієрейського собору 1944 р. щодо статусу церкви. І. Власовський вважав, що владика Діонісій тимчасово був кіріархом одночасно двох церков - православної церкви у Генерал-губернаторстві й УАПЦ: «Митрополит Діонісій, 3 благословення якого постав національний Собор єпископів Української Православної Церкви, не в'язав цього Собору і митрополита-адміністратора Церкви, які фактично були в управлінні церквою незалежними, а в той же час єднав їх 3 православним Сходом своїм канонічним авторитетом» ${ }^{36}$. Отже, на його думку, статус УАПЦ не змінився, вона й надалі де-факто залишалася помісною церквою.

Дещо іншої думки дотримується Ю. Мулик-Луцик: він переконував, що УАПЦ не була автокефальною церковною структурою і формально до 1946 р. підпорядковувалася польській церкві. Собор єпископів 1944 р. «не унезалежнив цих архієреїв від юрисдикції Варшавської Митрополії, бо... вищезгаданий Собор не нарушив дотогочасного статусу Адміністратури... Владика Полікарп далі залишається на статусі „адміністратора” (в юрисдикції митрополита Варшавського)» ${ }^{37}$. Автор зауважує, що сан обласного, а не єпархіального митрополита Полікарпу надав собор у Еслінгені в березні 1946 р., однак применшує той факт, що ще у Варшаві він отримав титул місцеблюстителя київського митрополичого престолу і став головою собору єпископів і Св. синоду УАПЦ. Подібну позицію займає і О. Хомчук ${ }^{38}$. Заради справедливості слід відзначити, що Варшавський Митрополит не втручався у справи української церкви і навіть не був присутнім на засіданнях собору.

${ }^{36}$ I. Власовський, op. cit., с. 273.

${ }^{37}$ С. Савчук, Ю. Мулик-Луцик, op. cit., с. 562.

${ }^{38}$ О. Хомчук, Церква поза церковною огорожею: розколи і руйнація Украйнської православної ичеркви в пошуках «константинопольського визнання», Chicago 2002, c. 298. 
Отже, роль митрополита Діонісія Валединського була визначальною в конституюванні УАПЦ років війни, яка була самостійною церквою з канонічним єпископатом і через варшавську митрополію перебувала у євхаристійному спілкуванні з іншими помісними церквами, крім Московського Патріархату, який до 1948 р. не визнавав польської автокефалії. Сдиний з ієрархів УАПЦ формації 1942 р. владика Мстислав Скрипник повернувся до України в 1990 р. і безпосередньо долучився до відродження автокефальної церкви та іiі нового єпископату.

\section{Архівні джерела}

Archiwum Warszawskiej Metropolii Prawosławnej, sygn. 1151-RII-6D (Cerkiew ukraińska w latach 1939-1944).

University of Alberta Archives, Accession 2011-27 (Minenko Collection), box 57, item 1404.

Державний архів Київської області, ф. 2412 (Музей-архів переходової доби), оп. 2, спр. 199, арк. 29-31, 75.

Центральний державний архів громадських об'єднань України, ф. 269, оп. 1, спр. 341, арк. 28-30.

\section{Література}

Dudra S., Metropolita Dionizy (Waledyński). 1876-1960, Warszawa 2010.

Mironowicz A., Kościót prawosławny na ziemiach polskich w XIX i XX wieku, Białystok 2005.

Божиею Милостию, возглавляюший Православную Русскую Церковь, патриарший местоблюститель, смиренный Сергий, митрополит Московский и Коломенский православным архипастырям, пастырями пасомым в областях Украины, пока еще занятых гитлеровскими войсками [online], http://www.sedmitza.ru/text/439907.html [доступ: 30.11.2017].

Борщевич В., Автономна Православна Церква на Волині, Луцьк 1998.

Борщевич В., Українське иерковне відродження на Волині (20-40-ві рр. $X X \mathrm{~cm}$.), Луцьк 2000.

Власовський І., Нарис історії Української Православної Церкви. Т. 4. ХХ ст. Ч. 2, Київ 1998. 
Дублянський А., Тернистим шляхом: життя митрополита Ніканора (Абрамовича), London 1962.

Мартирологія Українських Церков. Т. 1. Українська Православна Церква, Toronto, Baltimore 1987.

Міненко Т., Православна Церква в Україні під час Другої світової війни. 1939-1945 (Волинський період), т. 1, Winnipeg, Львів 2000.

Петрушко В., Автокефалисткие расколь на Украине и проблема их преодоления: канонический аспект [online], http://archive.li/uU5P [доступ: 19.11.2017].

[Ранєвський С.], Українська автокефальна иерква: історичний нарис про иерковний розкол на Украӥні, Хмельницький 1995.

Савчук С., Мулик-Луцик Ю., Історія Української Греко-Православної Церкви в Канадi. Т. 1. Київська церковна традиція українців Канади, Winnipeg 1984.

Смирнов А., Мстислав (Скрипник): громадсько-політичний і иерковний діяч. 1930-1944, Київ 2008.

Смирнов А., Почаӥвський иерковний Собор 18-23 серпня 1941 року, «Наукові записки Національного університету „Острозька академія”. Серія „Історичні науки"» 2015, вип. 24.

Стоколос Н., Конфесійно-етнічні трансформачії в Украӥні (XIX-nерша половина ХХ ст.), Рівне 2003.

Хомчук О., Церква поза церковною огорожею: розколи і руйнація Украӥнської православної иеркви в пошуках «константинопольського визнання», Chicago 2002.

Шкаровский М., Политика Третьего рейха по отношению к Русской Православной Церкви в свете архивных материалов (сборник документов), Москва 2003.

Шліхта Н., Церква тих, хто вижив. Радянська Украӥна, середина 1940-х початок 1970-х рр., Харків 2011.

\section{The role of the Metropolitan of Warsaw Dionisii Valedynskyi constituting the wartime Ukrainian Autocephalous Orthodox Church}

The article deals with external transformation of Ukrainian orthodoxy during the World War II. Special attention is paid to the canonical relations between the Warsaw Metropolitanate and the Moscow Patriarchate. Under German occupation, ukrainian orthodoxy split into two groups. One trend was led by Metropolitan Oleksii Hromadskyi, 
who created the Autonomous Orthodox Church under the Moscow Patriarchate. Metropolitan of Warsaw Dionisii Valedynskyi gave his blessing for the establishment of the Ukrainian Autocephalous Orthodox Church and designated Archbishop Polikarp Sikorskyi as administrator of the church. In February 1942 in Pinsk Sikorsky consecrated the first two bishops of the UAOC on Ukrainian territory (Nykanor Abramovych and Ihor Huba), and in May 1942 the Kyiv Council of UAOC bishops elected Dionisii as locum tenens of the Metropolitan See of Kyiv.

Keywords: Dionisii Valedynskyi, the Orthodox Church, Warsaw Metropolitanate, canonicity, hierarchy 